\title{
The contribution of monocytes/macrophages to HTLV-1 infection and persistence
}

\author{
Maria Fernanda de Castro-Amarante ${ }^{1 *}$, Cynthia Pise-Masison', Katherine McKinnon', Raya Massoud ${ }^{2}$, \\ Steven Jacobson ${ }^{2}$, Genoveffa Franchini ${ }^{1}$ \\ From 16th International Conference on Human Retroviruses: HTLV and Related Viruses \\ Montreal, Canada. 26-30 June 2013
}

Peripheral blood monocytes can be classified into three main subsets: $\mathrm{CD} 14^{++} \mathrm{CD} 16^{-}$(classical), $\mathrm{CD} 14^{+} \mathrm{CD} 16^{++}$ (non-classical), and $\mathrm{CD} 14^{++} \mathrm{CD} 16^{+}$(intermediate) which exert important roles in innate and adaptive immunity. Here we investigated whether the different monocyte subsets are potential HTLV-1reserviors that contribute to viral infection and persistence. PBMCs from 17 HTLV-1 infected patients (IP) and 11 normal donors (ND) were phenotypically analyzed by flow cytometry. Classical monocyte frequency was lower in HTLV-1-IPs compared to NDs $(\mathrm{p}=0.048)$. Moreover, we found a positive correlation between PVL and intermediate monocyte frequency $(\mathrm{r}=0.6735, \mathrm{p}=0.0042)$. Focusing on the presence of HTLV-1 provirus DNA in the different monocyte subsets, cell populations were isolated from PBMCs of 16 HTLV-1-IP. When we analyzed by nested PCR genomic DNA isolated from sorted CD4+, CD8+ $\mathrm{CD} 14^{++} \mathrm{CD} 16^{-}, \mathrm{CD} 14^{+} \mathrm{CD} 16^{++}$, and $\mathrm{CD} 14^{++} \mathrm{CD} 16^{+}$, we found that HTLV-1 patients with high PVL, all monocyte subsets as well as CD4+ and CD8+ cells were positive for HTLV-1. In contrast, the intermediate monocytes were negative or very weakly positive for HTLV-1 in patients with low PVL. To test whether natural STLV-1 infection recapitulates what we find in HTLV-1-IPs, we analyzed the monocyte subsets distribution in 8 STLV-1 infected Rhesus macaques and 16 naïve animals. Consistent with human infection, the frequency of intermediate monocytes was higher in infected macaques compared to naïve animals ( $\mathrm{p}=0.0001$ ) with a positive correlation between PVL and intermediate monocytes frequency $(\mathrm{r}=0.6530, \mathrm{p}=0.03)$. In conclusion, our results suggest that monocytes play

\footnotetext{
* Correspondence: amarantem@mail.nih.gov

'Animal Models and Retroviral Vaccines Section, National Cancer Institute, Bethesda, MD, USA

Full list of author information is available at the end of the article
}

an important role in viral dissemination and persistence and are potential viral reservoirs.

\section{Authors' details}

${ }^{1}$ Animal Models and Retroviral Vaccines Section, National Cancer Institute, Bethesda, MD, USA. 'Viral Immunology Section, Neuroimmunology Branch, National Institute of Neurological Disorders and Stroke, Bethesda, MD, USA.

Published: 7 January 2014

doi:10.1186/1742-4690-11-S1-P123

Cite this article as: de Castro-Amarante et al:: The contribution of monocytes/macrophages to HTLV-1 infection and persistence. Retrovirology 2014 11(Suppl 1):P123.

Submit your next manuscript to BioMed Central and take full advantage of:

- Convenient online submission

- Thorough peer review

- No space constraints or color figure charges

- Immediate publication on acceptance

- Inclusion in PubMed, CAS, Scopus and Google Scholar

- Research which is freely available for redistribution 